Torsten Wilholt

\title{
Scientific Autonomy and Planned Research: The Case of Space Science
}

[Manuscript version. Original publication appeared in

Poiesis and Praxis 4 (4), 2006, 253-265.]

\begin{abstract}
Scientific research that requires space flight has always been subject to comparatively strong external control. Its agenda has often had to be adapted to vacillating political target specifications. Can space scientists appeal to one or the other form of the widely acknowledged principle of freedom of research in order to claim more autonomy? In this paper, the difficult question of autonomy within planned research is approached by examining three arguments that support the principle of freedom of research in differing ways. Each argument has its particular strengths and limitations. Together they serve to demonstrate particular advantages of scientific autonomy, but in the case of space science, their force ultimately remains limited. However, as the arguments highlight the interrelations between scientific autonomy, the democratic process and the collective interest in scientific knowledge, they suggest that a coherent and sustained space science agenda might best be ensured by increasing the transparency of science policy decisions and involving the democratic public.
\end{abstract}

\section{Space Science and the Freedom of Research}

It is befitting to begin a paper on scientific autonomy with a reference to Wilhelm von Humboldt. The words he used in an 1810 government memorandum on the organization of the academic institutions in Berlin were to be inscribed in the cultural memory of generations of German-speaking scholars and scientists. With regard to both the Preußische Akademie der

\footnotetext{
* Dr. Torsten Wilholt, Abteilung Philosophie, Universität Bielefeld, Postfach 100 131, 33501 Bielefeld.

E-mail: twilholt@uni-bielefeld.de , Tel.: 0521 - 1064605.
} 
Wissenschaften (Prussian academy of sciences) and the university that was just in the process of being founded, he declared:

These institutions can only fulfill their purpose if each of them, as much as possible, confronts the pure idea of science [Wissenschaft ${ }^{1}$; hence, solitude and freedom are the principles prevailing in their sphere. (Humboldt 1810, 255)

Our interest in Humboldt's memorandum extends beyond this famous dictum. Not only does he stipulate the freedom of science from external obstruction; he explicitly postulates an obligation of the state to actively promote science. In doing so, says Humboldt, the state must always be aware

... that it always hinders, as soon as it intervenes; that the matter as such would work infinitely better without it; and that actually things are just as follows: Since in a positive society, any extended activity requires outer forms and means, the state has an obligation to provide these also for the realization of science [...]. (Ibid., 257)

The idea did not prevail that the state would have to add an apology to each transfer of the required means for scientific inquiry. The principle of freedom of research, however, became widely acknowledged. In its outline for a German constitution, the 1848 constitutional assembly in the Paulskirche in Frankfurt adopted the proposition: "Science [Wissenschaft] and its teaching are free." Friedrich Wilhelm IV took on the same sentence and included it the constitution he imposed on Prussia on December 5th, 1848, making the freedom of research a legal norm for the first time. Austria followed in 1867. (Cf. Schmidt 1929, 6077)

Since then, the freedom of academic teaching and research has had a firm place in German and Austrian constitutional history. The present formulation in the German constitution is: "Art and science [Wissenschaft], research and teaching are free" (Grundgesetz article 5, sec. 3). But also outside the Germanspeaking countries, some variant of the principle of freedom of research is often a pivotal point in debates about science policy or about research ethics. An extraordinary example of this is provided by the referendum on stem cell research held by the state of California in November 2004. It resulted in the Californian electorate accepting a law that seeks to establish guaranteed and autonomous stem cell research in their state and that contains the remarkable

\footnotetext{
${ }^{1}$ Note that the concept of Wissenschaft comprises not only the sciences but also the humanities.
} 
declaration "There is hereby established a right to conduct stem cell research." (Attorney General of the State of California 2004, 147, cf. Brown und Guston 2005)

However, juridical questions concerning the freedom of research are not the concern of this paper. Rather, I will pursue the question whether or not the claim that decisions about research projects should be made within the scientific disciplines concerned and in as independent a manner as possible can be justified. The justification at issue must be understood in a broadly normative, non-juridical sense. The question requires a closer look at the grounds of the principle of freedom of research, and an assessment of their strengths and limitations. As a particularly interesting special case of application, I will consider space science. By space science, I understand all scientific research that requires space flight (crewed or uncrewed). Can space scientists appeal to the principle of freedom of research to claim autonomy in their research decisions?

Being "Big Science", space science has been subject to comparatively strong political control from the onset. It may nevertheless make sense to inquire whether the case for freedom of research can be made even within space science. Firstly, space flight provides many illustrations of the claim that politics "always hinders" as soon as strategic decisions have to be subjected to its logic. German contributions to space science in particular have not infrequently been afflicted with incoherent political requirements and the ensuing half measures. An example is Germany's long-lasting see-saw between a European space policy and stronger transatlantic cooperation, which in the end contributed to the outcome that numerous European projects ultimately lacked the support required for successful completion while at the same time Germany never managed to outgrow the status of junior partner in its cooperation with the US and was therefore often forced to accept set-backs to its space science projects. (Cf. Weyer 2006 and Reinke 2004, chs. 4 and 5)

Secondly, political requirements are to an ever-increasing degree leaning towards a concentration on application-oriented research goals. In space science as in other areas of the sciences qualms are growing that externally imposed aims more and more outbalance the research aims that result from the disciplines' own inner dynamics. A neglect of basic science is often feared to be the consequence. (Cf. for example Ziman 2003, cf. also Wilholt 2007, Adam, Carrier and Wilholt 2006)

Is there a defensible principle of freedom of research that can serve to substantiate the claim that external instrumentalization of space science is 
illegitimate and that society or the state is obliged to facilitate, as far as possible, the free exploration of space? That is the guiding question behind the considerations of this paper.

But first it has to be acknowledged that this kind of question affords only a very selective perspective on space flight. From the state's perspective, space flight serves not only scientific purposes, but also other tasks of the state. An important case is infrastructure policy, where the applications of satellite technology play an important role in areas such as communication, meteorology, navigation and geodesy. Military and security policy are obviously often important for governmental interest in space flight (and concern not only satellites but also rocket technology as well as the hypersound and re-entry technologies of space gliders), though they have been of lesser concern in recent German space flight policy. Nevertheless, in Germany and elsewhere, space-flight is a cross-sectional task, involving other functions of the state in addition to the encouragement of the sciences (cf. Spude 1995, ch. C). These functions may not always be separable, and this alone may already imply a fundamental limitation to the freedom of research in space science.

Nevertheless, if there was a convincing argument that society or the state must sponsor the sciences in their free development, i.e. in their evolvement in all relevant directions and in accordance with the dynamics determined by the disciplines' own development, and if said relevant directions included the research strands pursued in space science, then free choice of projects for the disciplines involved in space science should be stipulated at least within the leeway left by the other functions of space flight. The question remains whether a principle of freedom of research of the required form and strength can be justified. I will now outline three possible arguments for freedom of research and put them to the test with regard to their significance for the case of space science. It is, after all, far from self-evident that scientific research, in contrast to many other collective activities supported by society, should enjoy a guarantee of freedom. Why is it that research should be free?

\section{Arguments for freedom of research}

\section{The argument from autonomy}

The first possible line of reasoning we have to consider is an argument from autonomy. It can be argued that knowledge is one of the basic requirements an individual needs in order to live a self-determined life. The individual must 
therefore possess the right to acquire this knowledge, which implies the right to engage in inquiry. This connection between freedom of research and individual autonomy suggests itself most immediately with regard to Humboldt, who prominently emphasized the ethical value of autonomy:

The true purpose of a human being - the one not dictated by changing affection, but by eternally unchanging reason - is the greatest and most well-proportioned development [Bildung] of its powers to a whole. Freedom is the first and indispensable condition of this development. (Humboldt 1792, 21)

Surely such a principle of autonomy permits the derivation of an extensive right of the individual to conduct knowledge-oriented endeavors (as long as they do not conflict with other rights). For this reason, the argument from autonomy is even in our times still sometimes regarded as the central argument for academic freedom (cf. Putnam 1987, 45). However, the argument as such does not seem to entail more than that individuals should not be obstructed in their efforts to increase their knowledge. It can in no obvious way be concluded from the value of individual autonomy alone why society or the state must pick out some knowledge-oriented enterprises (viz., scientific research), acknowledge them as collective tasks, and actively promote their development. Yet according to a widespread understanding of the principle of freedom of research, it entails a claim to public support. To understand this important aspect, we have thus to consider additional arguments.

\section{The argument from democracy}

A second argument that might be called the argument from democracy holds promise of strengthening the principle of freedom of research. The democratic process presupposes, among other things, the citizens' capacity to form wellfounded beliefs about the possible consequences of governmental and legislative decisions and to develop reasoned preferences among them. These tasks obviously require knowledge. Theorists of democracy have therefore derived a right to free inquiry from these presuppositions (Dahl 1985, cf. Brown \& Guston 2005, 9).

This second root of the principle of freedom of research also goes back at least to Enlightenment thought, ${ }^{2}$ as evidenced most strikingly by a report that

\footnotetext{
${ }^{2}$ Political considerations in the widest sense in favor of the libertas philosophandi were already formulated by Spinoza (1670, ch. 20), who argued that human beings were by their nature incapable of giving up that freedom, such that any governmental attempt to restrict the freedom
} 
was submitted in 1792 to the Legislative National Assembly in Paris by the Marquis de Condorcet. He had been commissioned to propose ideas for the new organization of Science and Education in post-revolutionary France. In the report, he wrote:

Finally, no public power must have the authority, not even the standing, to prevent the development of new truths or the teaching of such theories that contradict its particular politics or its present interests. (Condorcet 1792, 453)

Accordingly, he suggests that entities which are independent from the government should be in charge of the appointment of professors, the oversight of textbooks, and similar things. He explains that the continuous progress of the republic calls for unremitting criticism, and that a public authority interfering with academic matters would thereby "contradict the purpose of the whole social institution: the perfecting of the laws." (Ibid., 523)

Today, the plausibility of an argument from democracy for freedom of research has rather increased. Participation in democratic processes now virtually always requires knowledge about complex affairs by far surpassing whatever knowledge might be produced by the citizens' private research efforts. They are therefore reliant on knowledge institutions, including not only varied and independent media, but also a public science that must be largely independent from the government and from the parties involved in the political process. This independence must extend, not only to free communication of scientific knowledge, but also to independent decision-making concerning the inception and continuation of research projects. If, for example, citizens are to put trust into the findings of academic toxicology concerning the toxicity of certain substances, then academic toxicologists have to be able to select and carry out research projects in a way that is free from political interference.

The bearing of the argument from democracy on the case of space science may be less obvious than in the case of toxicology. But a recent example can demonstrate the relevance. The administrators of NASA recently decided to halt a mission called Deep Space Climate Observatory (Lawler 2006a). The satellite, though almost completed, was put in moth-balls and might never be launched. The first plans for this mission had been set up during the time of the Clinton administration, when it had been strongly supported by vice-president Al Gore.

of philosophizing could only be enforced by violent means and would thus inevitably lead to tyranny. 
The satellite's most important purpose would have been to provide reliable data about the earth's changing albedo (i.e. its reflectivity of the sunlight). NASA explains that the costs for launching the satellite are too high, which is consistent with its large number of recent terminations of science missions for budget reasons (Reichhardt 2006a, Lawler 2006b). However, the earth's albedo is one of the decisive and controversial quantities in the scientific study of climate change (Charlson et al. 2005). In view of the Bush administration's wellknown stance on climate policy and its well-documented attempts to suppress scientific evidence for human-caused climate change (UCS 2005, 5-8), the relevance of the termination of the Deep Space Climate Observatory mission for the democratic process can not be easily dismissed. NASA's decision may have been an act of anticipatory obedience or it may have resulted from a more immediate form of political influence - in either case the citizens' interest in independent, robust knowledge was not served well.

The argument from democracy is a strong argument in the sense that protecting the preconditions of the democratic process certainly deserves high priority. What may be questioned is the scope of a principle of freedom of research as supported by an argument from democracy. In order to support the well-informed and unmanipulated judgment of citizens with respect to political decisions, it may suffice to guarantee independent research decisions to the scientific disciplines only with respect to such projects that can be expected to result in politically relevant knowledge. This would certainly include projects in climate research, while mapping the stars, for example, does not seem to have a discernable relevance for the democratic process. (To be sure, it is always possible that research projects produce knowledge which then surprisingly gains previously unexpected relevance for seemingly unrelated matters. However, if the relevance is truly unforeseeable in advance, then there is also no danger of targeted manipulation through meddling with prior research decisions.) The argument from democracy is therefore a strong argument for a principle with limited scope - limited to research projects of political relevance. ${ }^{3}$

The example of the Deep Space Climate Observatory shows that there are in fact cases of space science projects with foreseeable politically relevant results. Further examples surely can be found, especially in the area of earth observation. However, they contrast with a large number of projects that lie

\footnotetext{
${ }^{3}$ The obvious problem arises of how to delineate the realm of "politically relevant" projects in practice-especially since the political relevance of a project may often be hidden in its details, as the case of the Deep Space Climate Observatory illustrates. This task will require a growing critical public attention to science and science policy.
} 
clearly beyond the reach of the argument from democracy. The search for gravitational waves, the geology of Mars and the quest for dark matter may exemplify this point. It is noticeable that among the projects that do not seem to be able to derive a claim to autonomy from the argument from democracy there are particularly many that are less application-oriented and rather associated with basic science. Thus it seems that if there is any hope at all of countering the external instrumentalization of space science with a substantiated claim for freedom of research, it will have to rest on yet another argument.

The argument from social epistemology

Our common interest in knowledge evidently surpasses the realm of information that is immediately relevant for political decision. This insight might provide us with a starting-point for a rationale for freedom of research with greater scope. Beyond as well as within the political sphere, we need knowledge to approach practical problems efficiently. We also search for knowledge in order to explain the phenomena of empirical reality and understand our place within it. The sciences can be regarded as the institutionalized endeavor to produce, by means of a cooperative effort, this knowledge that would be inaccessible to the epistemic pursuits of individuals. All this is well, but it does not yet explain why a principle of freedom of research should apply within the coordinated knowledge-generating enterprise. Could not the cooperative effort be orchestrated by a centralized authority and work equally well (and perhaps better)?

A riposte to this question that suggests itself is that organizing scientific inquiry on the basis of a principle of freedom of research is simply the most effective way to find as much relevant knowledge as possible in as quick and reliable manner as possible. I will call this way of justifying freedom of research the argument from social epistemology. Social epistemology is an emerging subfield of the theory of knowledge, whose core problem is, in the words of Philip Kitcher, "to identify the properties of epistemically well-designed social systems" $(1993,303)$. Is freedom of research one of these properties?

The argument from social epistemology must show that the principle of freedom of research outclasses other possible forms of organizing research - in particular such forms as resort to the external control or planning of research. For this reason, the fallibility of all attempts to plan and control research has played a central role in many historical instances of the argument from social epistemology. An impressive (and sadly forgotten) example of this is given in a 
lecture from 1711 by the philosopher and jurist Nicolas Gundling. In this address, much discussed in early 18th century Prussian academia, Gundling called for complete freedom of teaching and research for all four of the universities' faculties - a shocking conception at the time. (Gundling 1711, cf. Paulsen 1896, 530 f.) To him, this was the only way to increase the stock of known truths, because to purposefully plan a faultless way to new knowledge was in his view impossible.

Step by step must the summit of truth be scaled, which rises between a thousand rocks and shrubs of opinions, such that it is virtually impossible for even the most diligent not to slip here and there and collide and grasp false things, before they reach the place where there is no more occasion for erring and slipping. But now imagine that the erring were not tolerated, the deceived were suppressed, and the ones who had stumbled were trampled and chased away. Who could still ascend to that highest pinnacle of truth? Therefore, freedom must be conceded to reason. (Gundling 1711, 823)

The inference from fallibility to the desirability of free inquiry gained potency and popularity through John Stuart Mill's treatise On Liberty of 1859. Neither a person, nor a nation, nor a whole age can claim infallibility, says Mill. Therefore, an opinion may well be true while all contemporaries agree upon its falsehood. No opinion must therefore be suppressed, for this may possibly deprive mankind of an opportunity to exchange an error for a truth. (Mill 1859, 21-23)

Gundling's and Mill's considerations might be applied to the current matter of the freedom of research in the following manner. Prior judgments about the fruitfulness of research projects are generally fallible. Even projects that hold little promise of success from the point of view of the current scientific mainstream may therefore turn out to be groundbreaking. Consequently, scientists should choose their approaches and projects freely, such that a wide variety of approaches ends up being pursued. Some of them will prevail and lead to new knowledge, but it is impossible at any time to predict which ones these will be.

This approach accords well with the wide-spread view that scientific innovation can not be planned. The very novelty of innovative ideas or methods obviously limits the possibility to deliberately bring them about. Michael Polanyi advocated this point vehemently: 
You can kill or mutilate the advance of science, you cannot shape it. For it can advance only by essentially unpredictable steps, pursuing problems of its own, and the practical benefits of these advances will be incidental and hence doubly unpredictable. (Polanyi 1962, 62)

Polanyi was outraged by proposals of John Desmond Bernal and other British socialist scientists to introduce strong elements of socio-political planning into the organization of science in order to increase the social benefits derived from it. His ardent defense of the freedom of research must thus be seen in the context of its time, as a strong reaction to the perceived endangerment of freedom by the Bernalists (cf. Mirowski 1997). But a proponent of the argument from social epistemology need not adopt Polanyi's radical view that scientific progress can not be planned at all. The weaker claim that the planning of scientific progress is fallible and limited in its possibilities is already a promising starting point. The argument banks on the pluralism of scientific projects and approaches that evolves under conditions of free choice of projects and that counteracts the limitations and fallibility of planned procedure in the sciences.

Social epistemology suggests that under conditions of free choice of research projects the meritocratic organization of the sciences brings about an automatic division of cognitive labor. Individual scientists are awarded scientific credit for coming up first with an important finding. In their quest for credit, they must therefore look out for a research project where their individual chance to achieve such a success is high. For example, a researcher might also switch to an apparent outsider approach, as soon as all the overrun mainstream approaches hold no more attractive prospects of individual success for another competitor. In this way, even unorthodox approaches will receive a share of the whole scientific effort. (Cf. Kitcher 1993, ch. 8)

An advantage of the argument from social epistemology is that it holds for all disciplines that make an effort to produce new knowledge in innovative ways. Insofar as a strong common interest in this new knowledge exists, the argument can help to support the claim that there is an obligation of the public to facilitate free research within these disciplines by providing the required means. (The common interest in question may arise from the relevance of the new knowledge to the solution of our problems or to our understanding of the world and our place within it.) The argument is thus stronger than the argument from autonomy; at the same time, it has a wider scope than the argument from democracy. 
Let us assume that the research projects of space science can be considered as pursuing knowledge that is at large in the common interest. Still, a difficult obstacle lies in the way of applying the argument from social epistemology to the case of space science. It is built into the kind of freedom of research that can be supported by the argument. The argument from social epistemology capitalizes on epistemic advantages that result from the pluralism of approaches which is brought about by the free competition of rivaling projects. The principle of freedom of research that is supported by the argument must therefore include free choice of projects on the level of research groups or even individual researchers in order to guarantee a pluralism of actually implemented approaches.

In space science, it is doubtful whether this kind of pluralism can exist at all. The capacity of space flight is limited by its excessive cost, such that only a small number of selected projects can actually be executed. Like other areas of Big Science, space science is doomed to be planned science due to limited resources. (Note that the present situation in space science may foreshadow a more general future predicament of science organization, as innovative scientific research is generally becoming ever more expensive.) The resources for space science will always be subject to political deliberation and hence be limited not only by natural constraints. After all, the knowledge aims of space science are at best one matter of public interest among many others, against which they have to be balanced. In a world of scarce resources, free choice of research projects in space science on the level of research groups or even individual scientists is thus an unrealistic fiction.

If any principle of scientific autonomy was to be applicable to space science, it would therefore have to be the kind of principle that operates on the level of disciplines (or even the scientific community) and stipulates that decisions about the inception and continuation of research projects must be free from extra-disciplinary (or extra-scientific) intervention. But this kind of claim is generally hard to justify - except maybe for the limited domain where the argument from democracy holds sway. It is far from obvious that intradisciplinary decisions more often achieve the goal of increasing the kind of new knowledge that is in the public interest than extra-disciplinary ones. It might be adduced that good decisions in planning research require concentrated specialized knowledge and competence, which is usually found rather within than without the scientific disciplines. However, that insight amounts to no more than a plea for competently informed research decisions. Decision-makers 
should of course make use of the best expertise available, but that alone does not entail that the sciences must decide autonomously.

\section{Epilogue}

In January 2004, George W. Bush announced his Vision for Space Exploration. The declared goals of a new crewed moon mission and, as a superordinate aim, a crewed mars mission have massively changed the priorities of the American space program. Consequently, the new NASA director Michael Griffin had to execute cutbacks in many places of the budget (Reichhardt 2006a, Lawler 2006b). NASA's science missions are affected by the cutbacks to a disproportionately high degree, as was criticized by a report issued by the Space Studies Board of the National Academies (Space Studies Board 2006). The development of whole sub-disciplines, like astrobiology, might be stifled by the cutbacks (ibid., 30). Of course, space programs world-wide are affected by the American decisions. (In Germany, this was felt most clearly in the case of the infrared telescope Sofia, a cooperative mission of NASA and the German space agency DLR. In its budget draft for 2007, NASA had first unilaterally stalled the project. Only after vehement protests by the DLR and favorable technical reviews was the decision later reversed.) Many scientists are unsatisfied with the new American priorities and are skeptical about the scientific fertility of a new moon mission, especially as related to its costs. In an interview, Griffin commented on the discontent that is widespread among scientists.

I have to draw the line when people say "I'm not interested in the Moon. I would rather put the money into studying the physics of the tropopause." OK, great. Glad you have an opinion; everybody gets one. But the people who run the country have decided that we are in fact going to the Moon. It's a question of what scientists would like to do with that. (Reichhardt 2006b)

This attitude seems difficult to accept - not only from the perspective of the scientists involved in the slashed projects. But our search for ways to apply principles of scientific autonomy to the case of space science has produced mostly negative results. Does this ultimately mean that there remains nothing to be said against Griffin's laconic statement?

Such a resigned stance is not justified by the considerations presented in this paper. As the discussion of the argument from social epistemology has shown, the state's duty to sponsor scientific research arises from the collective 
interest in knowledge that could not be attained by the citizen's private efforts. To do justice to this purpose of the public support for science, strategic decisions must in the first place adequately reflect the collective interest in knowledge. Secondly, they must make use of the best available expert knowledge in order to determine how best to realize this interest. One may speculate that some of the procedures that led to recent important decisions affecting space science lacked one or both of these requirements.

A crucial problem is that science policy decisions are often achieved by processes of scant transparency to the public. In a democratic society, the public should participate in the determination of collective knowledge aims. In the absence of public attention, space science easily becomes a plaything for political agents who are dealing with aims and interests that have little or nothing to do with acquiring new knowledge, such as industry policy, international politics, military use, or propaganda. The incoherencies and instabilities in space science programs world-wide are not a consequence of a lack of scientific autonomy, but often result from a lack of democratic culture in science policy making.

It is therefore of greatest concern, also to the scientific community, to frame decision-making processes in space policy in a more transparent way and to generate more public attention for them. It follows that if the space science community wants to substantiate its claim to reliable support for its own chosen research projects, then it can best do so by convincing the democratic public of the following three ideas:

(1) That basic as well as application-oriented research in space science aims at knowledge which is of collective interest,

(2) that only the sustained, stable and coherent support of space science programs can bring research closer to attaining these knowledge aims and

(3) that procedures of decision-making that forego the best available expert knowledge, which can be found within the respective scientific disciplines, constitute an irresponsible handling of limited resources.

Since it proves unfeasible to screen off the fate of space science from the sphere of politics by means of an appeal to a strong and sweeping principle of freedom of research, the future of space science will remain a political question through and through, which will ideally be resolved by means of democratic deliberation. 


\section{References}

Matthias Adam, Martin Carrier and Torsten Wilholt 2006: "How to Serve the Customer and Still Be Truthful: Methodological Characteristics of Applied Research", Science and Public Policy 33 (6), pp 435-444.

Attorney General of the State of California 2004: “Text of Proposed Laws: Proposition 71", $<$ http://vote2004.ss.ca.gov/voterguide/propositions/prop71text.pdf>.

Mark B. Brown and David H. Guston 2005: "Preface to a Democratic Theory of Science: The Right to Research", Online Newsletter of the Consortium for Science, Policy \& Outcomes, Arizona State University, $<$ http://www.cspo.org/ourlibrary/documents/right_to_research.pdf $>$.

Robert J. Charlson, Francisco P. J. Valero and John H. Seinfeld 2005: “In Search of Balance", Science 308, pp 806-807.

Marie Jean Antoine Nicolas Caritat Marquis de Condorcet 1792: "Rapport et projet de décret sur l'organisation générale de l'instruction publique”, in: Oeuvres de Condorcet, vol. 7, ed. by A. Condorcet O'Connor and M. F. Arago, reprint, Stuttgart-Bad Cannstatt: Frommann 1968, pp 449-573.

Robert A. Dahl 1985: A Preface to Economic Democracy, Los Angeles: University of California Press.

Nicholas Gundling 1711: „De Libertate Fridericianae“, in: Clarrissimorum virorum orationes selectae, ed. by Johann Erhard Kapp, Leipzig: Martini 1722, pp 803-836.

Wilhelm v. Humboldt 1792: Ideen zu einem Versuch, die Grenzen der Wirksamkeit des Staates zu bestimmen, Stuttgart: Freies Geistesleben 1962.

Wilhelm v. Humboldt 1810: „Ueber die innere und äussere Organisation der höheren wissenschaftlichen Anstalten in Berlin“, in: Werke in fünf Bänden, vol. 4, ed. by Andreas Flitner and Klaus Giel, 2nd ed., Darmstadt:

Wissenschaftliche Buchgesellschaft 1964, pp 255-266.

Philip Kitcher 1993: The Advancement of Science, New York etc.: Oxford Univ. Press.

Andrew Lawler 2006a: “NASA Terminates Gore's Eye on Earth”, Science 311, pp 26.

Andrew Lawler 2006b: "A Space Race to the Bottom Line", Science 311, pp 15401543.

John Stuart Mill 1859: On Liberty, in: On Liberty and Other Essays, ed. by J. Gray, Oxford etc: Oxford Univ. Press 1991, pp 1-128. 
Philip Mirowski 1997: “On Playing the Economics Trump Card in the Philosophy of Science: Why It Did Not Work for Michael Polanyi", Philosophy of Science 64 (Proceedings), pp S127-S138.

Friedrich Paulsen 1896: Geschichte des gelehrten Unterrichts auf den deutschen Schulen und Universitäten, vol. 1, 2nd ed., Leipzig: Veit.

Michael Polanyi 1962: "The Republic of Science: Its Political and Economic Theory", Minerva 1, pp 54-73.

Hilary Putnam 1987: "Scientific Liberty and Scientific Licence", Grazer Philosophische Studien 30, pp 43-51.

Tony Reichhardt 2006a: “US Space Scientists Rage over Axed Projects”, Nature 439, pp 768-769.

Tony Reichhardt 2006b: “Outspoken: Mike Griffin on the NASA Budget”, Nature 441, pp 134.

Niklas Reinke 2004: Geschichte der deutschen Raufahrtpolitik: Konzepte, Einflußfaktoren und Interdependenzen 1923-2002, München: Oldenbourg.

Space Studies Board 2006: An Assessment of Balance in NASA's Science Programs, Washington D.C.: National Academies Press.

Walter Schmidt 1929: Die Freiheit der Wissenschaft: Ein Beitrag zur Geschichte und Auslegung des Art. 142 der Reichsverfassung, Berlin: Stilke.

Baruch de Spinoza 1670: Tractatus theologico-politicus, in: Opera, vol. 3, ed. by Carl Gebhardt, Heidelberg: Winter 1925, pp 1-247.

Mathias Spude 1995: Raumfahrt als Staatsaufgabe: Eine Querschnittsaufgabe und die Organisation ihrer Wahrnehmung durch den Staat, Köln etc.: Heymanns 1995.

UCS 2004: Scientific Integrity in Policy Making: An Investigation into the Bush Administration's Misuse of Science, Cambridge, Mass.: Union of Concerned Scientists.

Johannes Weyer 2006: „Die Raumfahrtpolitik des Bundesforschungsministeriums", in: Das Wissensministerium, ed. by Niels C. Taubert and Peter Weingart, Weilerswist: Velbrück, in press.

Torsten Wilholt 2006: “Design Rules: Industrial Research and Epistemic Merit", Philosophy of Science 73, in press.

John Ziman 2003: "Non-instrumental Roles of Science", Science and Engineering Ethics 9, pp 17-27. 